\title{
Pengaruh Partisipasi Penyusunan Anggaran, Pemahaman Akuntansi Pemerintahan dan Budaya Organisasi Terhadap Kinerja Manajerial pada Pemerintah Aceh
}

\author{
Saiful Bahgia \\ Politeknik Kutaraja Banda Aceh, Kota Banda Aceh, Indonesia
}

\begin{abstract}
Abstrak. Penelitian ini bertujuan untuk menguji pengaruh partisipasi anggaran, pemahaman akuntansi pemerintahan dan budaya organisasi terbadap kinerja manajerial pada pemerintaban Aceh. Penelitian ini merupakan penelitian sensus penduduk karena selurub anggotanya sebagai responden. Populasi di sekitar Kepala SKPA (Pengurus Anggaran / PA) Pejabat Kenangan dan Tata Usaha (PPK-SKPA) yang berjumlab 74 responden. Alat analisis yang digunakan adalah analisis regresi linier berganda dengan menggunakan SPSS. Hasil penelitian menunjukekan babwa ketiga variabel bebas yaitu partisipasi penyusunan anggaran, pemahaman akuntansi pemerintaban dan budaya organisasi baik secara bersama-sama maupun secara parsial berpengaruh terhadap variabel terikat yaitu kinerja manajerial pada pemerintahan Aceh.
\end{abstract}

Kata kunci: Partisipasi Anggaran, Pemahaman Akuntansi Pemerintahan, Budaya Organisasi, Kinerja Manajerial.

\begin{abstract}
This study aimed to examine the effect of budget participation, understanding of governmental accounting and organizational culture on managerial performance in the Aceh government. This study is a population census since all members as respondents. The population around the head SKPA (Budget Administrator / PA) Finance and Administration Officer (PPK-SKPA) which amounted to 74 respondents. The analytical tool used is multiple linear regression analysis using SPSS. The results showed that all three independent variables, namely budgetary participation, understanding of governmental accounting and organizational culture either jointly or partially affect the dependent variable is managerial performance in the Aceh government.
\end{abstract}

Keywords: Budgetary Participation, Understanding Government Accounting, Organizational Culture, Managerial Performance. 


\section{Pendahuluan}

Kinerja merupakan suatu alat penilaian keberhasilan dalam suatu organisasi. Tingkat pencapaian pelaksanaan suatu kegiatan merupakan gambaran dari kinerja dalam mewujudkan sasaran, tujuan, visi dan misi yang tertuang dalam perencanaan strategi suatu organisasi. Persoalan dalam perencanaan dan penganggaran dinilai penting untuk dicermati karena dapat menjadi cerminan terhadap keberpihakan pemerintah terhadap masyarakat. Selain itu, gambaran dalam perencanaan anggaran juga dapat dijadikan indikator terhadap seberapa besar kebijakan pemerintah peduli dengan kesejahteraan rakyat. Perencanaan anggaran tidak hanya cukup dengan pelibatan masyarakat seperti Musrembang desa, kecamatan hingga kabuapten/kota.

Masih rendahnya kinerja SKPA juga dapat dilihat dari penilaian BPK-RI terhadap laporan keuangan Pemerintah Aceh Tahun Anggaran 2019 masih mendapatkan predikat Wajar Dengan Pengecualian atau Qualified Opinion (WDP). Penilaian tersebut berdasarkan bukti audit yang masih menjadi permasalahan yaitu pada tahun 2017 terjadi kasbon sebesar 429,4 juta yang belum diselesaikan. Kemudian terdapat Piutang Dana Bergulir yang belum ada rincian data penerima dan laporannya yang memadai, termasuk di dalamnya dana berasal dari proporsi $60 \%$ dana otsus.

Selain penganggaran, kinerja manajerial juga dapat dipengaruhi oleh budaya organisasi. Budaya organisasi merupakan sistem penyebaran kepercayaan (Isvandiari dan Purwanto, 2017) dan nilai-nilai yang berkembang dalam suatu organisasi dan mengarahkan perilaku anggota-anggotanya (Putra, 2015). Budaya organisasi dapat menjadi instrumen keunggulan kompetitif yang utama (Fidowaty dan Kurniati, 2016), yaitu bila budaya organisasi mendukung strategi organisasi (Sutrisno, 2019), dan bila budaya organisasi dapat menjawab atau mengatasi tantangan lingkungan dengan cepat dan tepat (Wiguna dan Dharmadiaksa, 2016).

Penyusunan RKA SKPA hingga laporan keuangan daerah oleh pihak manajerial harus dilakukan dengan akuntabel sebagai bentuk pertanggungjawaban pemerintah terhadap pengelolaan keuangan daerah, oleh karena itu diperlukan sumber daya manusia yang memiliki pemahaman akuntansi yang baik sehingga pelaporan yang dihasilkan sebagai bentuk pertanggungajawaban dapat diterima oleh pihakpihak yang membutuhkan serta dapat menjadi informasi bernilai bagi masyarakat.

Dalam hal ini, Pemerintah Daerah harus dapat menjadi subjek pemberi informasi dalam rangka pemenuhan hak-hak publik (Herawati, 2014), yaitu hak untuk diberi informasi, didengar aspirasinya dan diberi penjelasan serta dilayani secara baik. Kenyataannya ada beberapa permasalahan yang dihadapi oleh akuntabilitas laporan keuangan seperti yang diungkapkan Mardiasmo (2009) dalam rangka pertanggungjawaban publik, pemerintah daerah seharusnya melakukan optimalisasi anggaran yang dilakukan secara efisien dan efektif untuk meningkatkan kesejahteraan masyarakat.

\section{Literature Review}

\section{Kinerja Manajerial}

Kinerja merupakan prestasi kerja yang dicapai unit kerja dalam merealisasikan target yang telah ditetapkan (Ven dan Ferry, 2018). Instrumen kinerja terkait dengan pencapaian target kinerja kegiatan dari suatu program, akurasi (ketepatan dan kesesuaian) hasil, tingkat pencapaian program, dampak hasil kegiatan terhadap kehidupan masyarakat, kesesuaian realisasi anggaran dengan anggaran, pencapaian efisiensi operasional, perilaku pegawai (Wulandari dan Mutmainah, 2011). Byars dan Rue (1984) mengemukakan bahwa kinerja adalah hasil dari usaha seseorang yang dicapai dengan adanya kemampuan dan perbuatan dalam situasi tertentu. Jadi prestasi kerja merupakan hasil keterkaitan antara usaha, kemampuan dan persepsi tugas.

Kinerja manajerial menurut Mahoney dalam Leach-Lopez et al. (2007) yaitu kinerja aparat dilihat berdasarkan kemampuan aparat dalam melaksanakan tugas-tugas manajerial yang meliputi perencanaan, investigasi, koordinasi, supervisi, pengaturan staf, negosiasi dan representasi. 


\section{Partisipasi Penyusunan Anggaran}

Partisipasi adalah suatu perilaku, pekerjaan, dan aktifitas yang dilakukan oleh aparat pemerintah selama aktivitas penyusunan anggaran berlangsung. Partisipasi penyusunan anggaran diperlukan dikarenakan agar anggaran yang dibuat sesuai dengan realita/kenyataan yang ada (Brownell dalam Coryanata, 2003).

Partisipasi penyusunan anggaran merupakan ciri dari penyusunan anggaran yang menekankan kepada partisipasi aparat pemerintah daerah untuk mempertanggung jawabkan proses penyusunan anggaran (Matondang, Basri, Arfan, 2015). Sedangkan anggaran suatu rencana yang disusun secara sistematis yang meliputi seluruh kegiatan pemerintahan yang dinyatakan dalam unit (kesatuan) moneter dan berlaku untuk jangka waktu (periode) tertentu yang akan datang (Munandar, 2001).

Brownell dan Innes (1986) menyatakan bahwa partisipasi dalam penganggaran yaitu suatu proses partisipasi individu yang akan dievaluasi dan mungkin diberi penghargaan berdasarkan prestasi mereka pada sasaran. Menurut Muhammad (2017) manfaat dari partisipasi penyusunan anggaran adalah semakin banyak aparat pemerintah yang terlibat dalam partisipasi anggaran maka semakin mudah dan cepat dalam menyusun anggaran.

\section{Akuntansi Pemerintahan}

Menurut Arinta (2016) yang dimaksud dengan akuntansi pemerintahan adalah aplikasi akuntansi di bidang keuangan Negara (public finance), khususnya pada tahapan pelaksanaan anggara (budget execuation), termasuk segala pengaruh yang ditimbulkannya, baik yang bersifat seketika maupun yang lebih permanen pada semua tingkatan dan unit pemerintah. Akuntansi pemerintahan meliputi kegiatan penganalisaan, pencatatan, penyimpulan, pelaporan dan penginterpretasian transaksitransaksi unit agensi pemerintah.

Akuntansi pemerintahan (termasuk didalamnya akuntansi untuk lembaga-lembaga yang tidak bertujuan untuk mencari laba lainnya) adalah bidang akuntansi yang berkaitan dengan lembaga-lembaga pemerintahan dan lembaga yang tidak mencari laba (Baswir, 1989).

Karakteristik khusus dari akuntansi pemerintahan adalah menggunakan istilah dana (fund), sehingga sering disebut sebagai akuntansi dana (Gade, 1993). Sistem akuntansi pemerintahan direncanakan, diorganisasikan, serta dijalankan atas dasar dana (Pangkey dan Pinatik, 2016). Dana dalam akuntansi pemerintahan adalah satuan akuntansi dan fiskal (fiscal and accounting entity) dengan seperangkat buku besar yang mencatat kas dan sumbersumber keuangan lain beserta segala kewajibankewajiban yang berkaitan dan sisa modal atau saldo-saldo (Susanti, 2017), dan perubahanperubahannya, yang dipisahkan dengan maksud melaksanakan kegiatan khusus atau mencapai tujuan-tujuan tertentu sesuai dengan peraturanperaturan, restriksi-restriksi, pembatasanpembatasan tertentu (Manoppo dan Tirayoh, 2017).

\section{Budaya Organisasi}

Moeljono (2003) menyatakan bahwa budaya korporat atau budaya manajemen atau juga dikenal dengan istilah budaya kerja merupakan nilai-nilai dominan yang disebar luaskan didalam organisasi dan diacu sebagai filosofi kerja karyawan. Budaya organisasi sebagai nilai-nilai yang menjadi pedoman sumber daya manusia untuk menghadapi permasalahan eksternal dan usaha penyesuaian integrasi ke dalam perusahaan sehingga masing-masing anggota organisasi harus memahami nilai-nilai yang ada dan bagaimana mereka harus bertindak atau berperilaku (Susanto, 1997).

Robbins (1998) mendefinisikan budaya organisasi (organizational culture) sebagai suatu sistem makna bersama yang dianut oleh anggotaanggota yang membedakan organisasi tersebut dengan organisasi yang lain. Lebih lanjut, Robbins (1998) menyatakan bahwa sebuah sistem pemaknaan bersama dibentuk oleh warganya yang sekaligus menjadi pembeda dengan organisasi lain.

\section{Metodologi Penelitian}

Penelitian ini merupakan penelitian sensus karena semua anggota populasi dijadikan responden. Populasi dalam penelitian ini seluruh kepala SKPA (Pengguna Anggaran/PA) dan 
Pejabat Penatausahaan Keuangan (PPK-SKPA) yang berjumlah 74 responden. Metode kualitatif dan metode kuantitatif digunakan sebagai analisis data. Pada metode kualitatif, semua data yang terkumpul dianalisis secara kualitatif berdasarkan pendapat para ahli sebagai landasan teori. Kuesioner yang telah diisi oleh responden dikuantitatifkan terlebih dahulu sehingga menghasilkan keluaran-keluaran berupa angka yang selanjutnya dianalisis melalui program SPSS (Statistical Package for Social Science).

Setelah kuesioner terkumpul untuk melakukan analisis data perlu dilakukan uji validitas dan uji reliabilitas. Kedua pengujian ini dilakukan untuk mengetahui apakah alat ukur yang digunakan sesuai dengan yang diukur dan juga melihat konsistensi data yang dikumpulkan. Model dalam penelitian ini adalah:

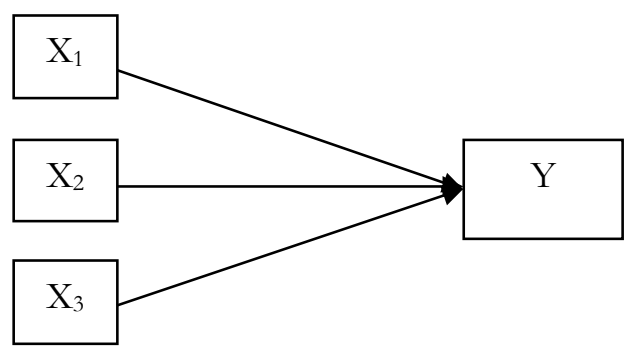

Gambar 1. Model Penelitian

\section{Pengujian Validitas dan Reliabilitas}

Penentuan validitas didasarkan atas Untuk mengetahui apakah instrumen yang digunakan memiliki validitas atau tidak, maka akan dilakukan pengujian statistik dengan menggunakan uji pearson product moment. Ukuran data dianggap valid apabila nilai korelasi lebih besar dari nilai kritis pada tingkat keyakinan $95 \%$.

Pengujian reliabilitas, umumnya pendekatan yang digunakan adalah dengan cara menghitung Cronbach Alpha masing-masing variabel yang terlibat. Cronbach Alpha menafsirkan korelasi antara skala yang dibuat dengan semua skala variabel yang ada. Dimana suatu instrumen dapat dikatakan reliabel bila memiliki koefisien keandalan atau nilai Cronbach Alpha lebih besar dari 0,5 (Nunnally dan Bernstein, 1994).

\section{Rancangan Pengujian Hipotesis}

Tehnik analisis data pada pengujian hipotesis menggunakan pengujian analisis regresi linier berganda yang merupakan tehnik statistik yang digunakan untuk menguji pengaruh antara dua atau lebih variabel dan untuk melihat pengaruh secara parsial dan simultan. Persamaan model empiris yang digunakan dalam meneliti pengaruh variabel independen terhadap variabel dependen yaitu:

$$
\mathrm{Y}=\alpha+\beta_{1} \mathrm{X}_{1}+\beta_{2} \mathrm{X}_{2}+\beta_{3} \mathrm{X}_{3}+\mathrm{e}
$$

Keterangan:

$\mathrm{Y}=$ Kinerja Manajerial

$\mathrm{X}_{1} \quad=$ Partisipasi Penyusunan Anggaran

$\mathrm{X}_{2} \quad=$ Pemahaman Akuntansi

Pemerintahan

$\mathrm{X}_{3} \quad=$ Budaya Organisasi

$\beta_{1}, \beta_{2}, \beta_{3}=$ Koefisien $X_{1}, X_{2}, X_{3}$

$\alpha \quad=$ konstanta

$\varepsilon \quad=$ error

\section{Hasil dan Pembahasan}

\section{Hasil Pengujian Validitas dan Reliabilitas}

Berdasarkan output komputer setelah dilakukan pengujian validitas seluruh pernyataan yang diajukan pada kuisioner telah valid (27 item pernyataan) dan memenuhi persyaratan untuk melakukan pengujian selanjutnya, dimana nilai koefesien korelasinya sudah lebih dari 0.244 (nilai kritis korelasi $\mathrm{r}$ product-moment untuk $\mathrm{n}=$ 68). Selanjutnya berdasarkan hasil pengujian reliabilitas terhadap variabel dalam penelitian ini menunjukkan bahwa pengukuran keandalan untuk masing-masing variabel independen dan dependen memenuhi persyaratan $\alpha>0.5$.

\section{Hasil Pengujian Hipotesis}

Melalui hasil program SPSS maka diperoleh persamaan regresi linier berganda pertama sebagai berikut:

$$
Y=1,184+0,871 X_{1}+0,689 X_{2}+0,699 X_{3}+e
$$

\section{Pembahasan}

\section{Pengaruh Partisipasi Penyusunan Anggaran terhadap Kinerja Manajerial}

Ikut berpartisipasinya apartur perangkat daerah dan diikuti dengan memberikan pendapat serta usulan dalam rangka penyusunan anggaran, maka akan lebih mudah bagi mereka untuk 
mengerti terhadap apa yang akan mereka kerjakan. Selanjutnya, partisipasi penyusunan anggaran akan membantu aparatur perangkat daerah untuk memperbaiki kinerja mereka dengan mengetahui target anggaran.

Brownell (1980) menemukan bahwa partispasi yang tinggi oleh pekerja dengan locus of control internal mengakibatkan kinerja yang meningkat, sedangkan partisipasi oleh pegawai locus of control external menghambat kinerja. Hal senada diungkapkan Li et al (2010) yang menyebutkan bahwa kunci kinerja manajerial yang efektif adalah partisipasi dari bawahan yang memegang peranan penting dalam pencapaian tujuan tersebut.

\section{Pengaruh Pemahaman Akuntansi Pemerintahan terhadap Kinerja Manajerial}

Data demografis responden menunjukkan sebanyak 32 responden (47,1\%) memiliki latar belakang ilmu akuntansi. Hasil ini memberikan makna bahwa akan lebih mudah bagi apartur perangkat daerah dalam memahami standar akuntansi pemerintahan sesuai dengan peraturan yang telah ditetapkan. PP Nomor 71 Tahun 2010 tentang Standar Akuntansi Pemerintahan menyebutkan definisi standar akuntansi pemerintahan adalah prinsip-prinsip akuntansi yang diterapkan dalam menyusun dan menyajikan laporan keuangan pemerintah.

Dalam lingkungan akuntansi pemerintahan, ciri-ciri penting lingkungan pemerintahan yang perlu dipertimbangkan dalam menetapkan tujuan akuntansi dan pelaporan keuangan adalah salah satunya anggaran sebagai pernyataan kebijakan publik, target fiskal, dan sebagai alat pengendalian. Fungsi anggaran di lingkungan pemerintah mempunyai pengaruh penting dalam akuntansi dan pelaporan keuangan, antara lain karena anggaran memberi landasan penilaian kinerja pemerintah.

\section{Pengaruh Budaya Organisasi terhadap Kinerja Manajerial}

Menurut Hofstede (1984), budaya selalu merupakan suatu perwujudan bersama, karena budaya setidak-tidaknya dirasakan sebagian orang hidup atau tinggal pada lingkungan sosial yang sama, dimana budaya dipelajari, yang membedakannya dengan orang diluar lingkungannya. Selanjutnya Hofstede (1984) menyatakan budaya organisasi adalah "The collective programming of mind which distinguishes the members of one organization from another". Budaya organisasi merupakan aspek penting dalam meningkatkan kinerja, maka budaya organisasi harus dikelola dengan baik.

Menurut Denison (1996) untuk menggunakan budaya organisasi sebagai kunci pengungkit perubahan organisasi dalam meningkatkan kinerja terdapat tiga pendekatan; pertama, membuat manajer sadar akan bukti-bukti yang menghubungkan budaya dan kinerja; kedua, membantu mereka mengerti pengaruh yang kuat, baik positif maupun negative dari budaya; dan ketiga, mendiskusikan budaya menggunakan bahasa yang dapat dimengerti manajer dan dapat cepat dihubungkan dengan perilaku mereka sendiri.

\section{Kesimpulan dan Saran}

Simpulan dalam penelitian ini adalah:

1. Partisipasi penyusunan anggaran, pemahaman akuntansi pemerintahan dan budaya organisasi berpengaruh positif secara bersama-sama terhadap kinerja manajerial pada Pemerintah Aceh.

2. Partisipasi penyusunan anggaran berpengaruh positif terhadap kinerja manajerial pada Pemerintah Aceh.

3. Pemahaman akuntansi pemerintahan berpengaruh positif terhadap kinerja manajerial pada Pemerintah Aceh.

4. Budaya organisasi berpengaruh positif terhadap kinerja manajerial pada Pemerintah Aceh.

\section{Daftar Pustaka}

Arinta, Kustadi. (2016). Pengantar Akuntansi Pemerintahan. Edisi Keenam. Bandung: PT. Citra Aditya Bakti.

Baswir, R. (1989). Akuntansi Pemerintahan Indonesia. BPFE Yogyakarta.

Brownell, P. (1980). Participation in Budgeting Process: When It Works and When It Doesn't'. Journal of Accounting Literature, Vol. 1 p. 124-153. 
Brownell, P., \& McInnes, M. (1986). Budgetary Participation, Motivation, and Managerial Performance. The Acccounting Review. Vol. LXI (4).

Byars, L. L., \& Rue, L. W. (1984). Human Resources \& Personnel Management. Richard D. Irwin. Inc., Homewood Illnois.

Coryanata, I. (2003). Pengaruh pelimpahan wewenang dan komitmen organisasi dalam hubungan antara partisipasi penyusunan anggaran dan kinerja manajerial pada perguruan tinggi swasta di Indonesia (Doctoral dissertation, [Yogyakarta]: Universitas Gadjah Mada).

Denison, D. R. (1996). What is the difference between organizational culture and organizational climate? A native's point of view on a decade of paradigm wars. Academy of management review, 21(3), 619-654.

Fidowaty, T., \& Sukaesih Kurniati, P. (2016). Pengaruh budaya organisasi terhadap kinerja dosen Universitas Komputer Indonesia (Unikom). JIPSI-Jurnal Ilmu Politik dan Komunikasi UNIKOM, 5(2).

Gade, M. (1993). Akuntansi Pemerintahan Edisi Revisi. Jakarta: Lembaga Penerbit Fakultas Ekonomi Universitas Indonesia.

Herawati, T. (2014). Pengaruh Sistem Pengendalian Intern Terhadap Kualitas Laporan Keuangan (Survei Pada Organisasi Perangkat Daerah Pemda Cianjur). STAR-Study \& Accounting Research, 11(1), 1-14.

Hofstede, G. (1984). Culture's consequences: International differences in work-related values (Vol. 5). Beverly Hilss: SAGE Publications.

Isvandiari, A., \& Purwanto, A. (2017). Pengaruh budaya organisasi, disiplin kerja, dan kepuasan kerja terhadap kinerja karyawan non medis rumah sakit islam malang. Jurnal Ilmiah Bisnis Dan
Ekonomi Asia, 11(1), 38-43.

Leach-López, M. A., Stammerjohan, W. W., \& McNair, F. M. (2007). Differences in the Role of Job-Relevant Information in the Budget Participation-Performance Relationship among US and Mexican Managers: A Question of Culture or Communication. Journal of management accounting research, 19(1), 105-136.

Li, W., Nan, X., \& Mo, Z. (2010, August). Effects of budgetary goal characteristics on managerial attitudes and performance. In 2010 International Conference on Management and Service Science (pp. 1-5). IEEE.

Mahoney, T. A. (1963). Development of managerial performance: A research approach. South-western Publishing Company.

Manoppo, M., Ilat, V., \& Tirayoh, V. Z. (2017). ANALISIS Efektivitas Anggaran Pendapatan Dan Belanja Daerah Pemerintah Kabupaten Bolaang Mongondow Timur (Tahun Anggaran 2014-2015). Jurnal EMBA: Jurnal Riset Ekonomi, Manajemen, Bisnis dan Akuntansi, 5(2).

Mardiasmo, A. (2002). Otonomi dan Manajemen Keuangan Daerah: Good Governance, Democratization, Local Government Financial Management.

Mardiasmo, D., \& MBA, A. (2009). Akuntansi Sektor Publik. Yogyakarta: ANDI.

Matondang, N. I., Basri, H., \& Arfan, M. (2015). Pengaruh Sinkronisasi Perencanaan dan Penganggaran, Partisipasi Anggaran dan Kejelasan Sasaran Anggaran Terhadap Kinerja SKPD pada Pemerintah Kabupaten Aceh Utara. Jurnal Administrasi Akuntansi: Program Pascasarjana Unsyiah, 4(4).

Moeljono, D. (2003). Budaya korporat dan keunggulan korporasi. Elex Media Komputindo. 
Munandar, M. (2001). Budgeting: Perencanaan

Kerja, Pengkoordinasian Kerja, Pengawasan Kerja. Edisi Pertama. BPFE Universitas Gajah Mada. Yogyakarta.

Nunnally, J. C., \& Bernstein, I. H. (1994). Psychometric theory 3rd edn. New York [etc].: McGraw-Hill.

Pangkey, I., \& Pinatik, S. (2016). Analisis Efektivitas dan Efisiensi Anggaran Belanja pada Dinas Kebudayaan dan Pariwisata Provinsi Sulawesi Utara. Jurnal EMBA: Jurnal Riset Ekonomi, Manajemen, Bisnis dan Akuntansi, 3(4).

Putra, S. W. (2015). Pengaruh Komitmen Organisasi, Budaya Organisasi, Gaya Kepemimpinan dan Lingkungan terhadap Kinerja Karyawan Pada Industri Kecil. Jurnal Ekonomi Modernisasi, 11(1), 62 77.

Robbins, S. P. (1998). Organization Behavior, Concepts, Controversies, Application. Englewood Cliffs dan PT. Prenhallindo, Jakarta.

Susanti, A. E. D. (2017). Penerapan Standar Akuntansi Pemerintahan Berbasis Akrual Dalam Penyajian Laporan Keuangan Pemerintah Daerah (Studi Kasus pada Dinas Pendapatan, Pengelolaan Keuangan dan Aset Daerah Kabupaten Gresik) (Doctoral dissertation, Universitas Muhammadiyah Gresik).
Susanto, A. B. (1997). Budaya Perusahaan. Manajemen dan Persaingan Bisnis, Elex Media Komputindo, Jakarta.

Sutrisno, H. E. (2019). Budaya organisasi. Prenada Media.

Van de Ven, A. H., \& Ferry, D. L. (1980). Measuring and assessing organizations, Wiley. New York, NY.

Wiguna, D. M. A. P., \& Dharmadiaksa, I. B. (2016). Pengaruh penerapan sistem informasi akuntansi terhadap kinerja individual dengan budaya organisasi sebagai pemoderasi. E-jurnal Akuntansi, 17.

Wulandari, N. E., \& Siti Mutmainah, S. M. (2011). Pengaruh Partisipasi Penyusunan Anggaran Terhadap Kinerja Aparat Pemerintah Daerah: Kepuasan Kerja dan Komitmen Organisasi Sebagai Variabel Moderating (Studi Empiris Pada Pemerintah Daerah Kabupaten Demak) (Doctoral dissertation, Universitas Diponegoro). 